\title{
Prevalence and characterization of Salmonella species isolated from broilers
}

Elsayed M.E. ${ }^{1}$; Esawy A. M. ${ }^{2}$; Elsotohy M.E. ${ }^{2 *}$

1. Faculty of Veterinary Medicine, Suez Canal University. 2, 2*. Animal Health Research Institute - Mansoura, Dakahlia.

\begin{abstract}
This study was conducted to determine the prevalence of Salmonellae in broilers farms in Dakahlia Governorate, Egypt. A total of 1000 samples that collected from 200 broiler chickens (40 apparently healthy, 80 diseased chickens and 80 freshly dead broiler chickens).These samples included liver, caecum, heart blood, spleen $\&$ kidney. The colonial morphology, microscpical and biochemical identifications of the isolates revealed the presence of 37 Salmonella isolates out of 200 chickens (18.5\%) representing: 3 from apparently healthy chicken (7.5\%), 21 from diseased chickens (26.25\%) and 13 from freshly dead broiler chickens $(16.25 \%)$. The rate of recovery of Salmonellae from the different internal organs showed that high recovery rate was from liver, caecum, spleen, heart then kidney as the follow $(9.5 \%),(5.5 \%),(4.5 \%),(3 \%)$ and $(2 \%)$, respectively. The serotyping of the isolated salmonellae from chickens were eight $S$. enteritidis, one $S$. maccles Field, two $S$. wingrove, one $S$. eingedi, three $S$. rissen, two $S$. derby, two $S$. vejle, one $S$. magherafelt, two $S$. berta, two $S$. enterica sub.spp salamae, one $S$. gueuletapee, one $S$. blegdam, five $S$. kentucky, two $S$. newport, two $S$. agona and two $S$. virchow. Gentamycin, ciprofloxacin, colistin sulphate and enrofloxacin were found to be the most effective antimicrobials drugs while erythromycin and flumequine were the most resistant antibiotic against the isolates. PCR assay was carried out for six serovars (S. enteritidis, S. maccles Field, S. rissen, S. derby, S. magherafelt and $S$. enterica sub.spp salamae) to detect the presence of invA, sopB and stn genes. All serovars had the three genes.
\end{abstract}

Keywords: Salmonella spp., Broilers, Prevalence, characterization

\section{Introduction}

Salmonella infection is one of the most serious problems that affect poultry industry causing high economical losses not only due to high mortality in young chickens but also for the debilitating effect which predisposes for many other diseases. Salmonellosis is an important health problem and a major challenge worldwide. Salmonella spp. are recognized as the most causative agents of food poisoning. These organisms are Gram negative and rod shape which have been divided into over 2700 
serotypes based on somatic, flagellar and capsular antigens (Gallegos et al, 2008). Salmonellae are short bacilli, 0.7-1.5 × $2.5 \mu \mathrm{m}$, Gram-negative, aerobic or facultative anaerobic, positive catalase, negative oxidase; they ferment sugars with gas production, produce $\mathrm{H} 2 \mathrm{~S}$, are non sporogenic, and are normally motile with peritricheal flagella, except for Salmonella Pullorum and Salmonella Gallinarum, which are nonmotile (Forshell and Wierup, 2006).

The genus Salmonella is divided into two species Salmonella enterica and Salmonella bongori; Salmonella enterica itself is comprised of 6 subspecies. They are $S$. enterica subsp. enterica, $S$. enterica subsp. arizonae, S. enterica subsp. diarizonae, $S$. enterica subsp. indica, S. enterica subsp. houtenae or I, II, IIIa, IIIb, IV and $V I$, respectively (Popoff and Minor, 1997).

Salmonella enterica serovar typhimurium and $S$. enterica serovar enteritidis are the most frequent isolated serovars worldwide (Chiu et al, 2010). In Egypt S. enteritidis were isolated from broiler chicken, chicken meat and food poisoning patient. The clinical illness characterized by fever, nausea and diarrhea, vomition and abdominal pain after an incubation period of 12 to $72 \mathrm{hrs}$ (Ammar et al, 2010).

Many of the virulence genes of $S$. enterica are chromosomal genes located on pathogenicity islands referred to as Salmonella Pathogenicity Islands (SPI). These genes are believed to have been acquired by Salmonella from other bacterial species through horizontal gene transfer. They responsible for host cell invasion and intracellular pathogenesis. Other virulence factors of Salmonella include production of endotoxins and exotoxins, and presence of fimbrie and flagella (van Asten \& van Dijk, 2005).

This study was planned to identify biochemically and serologically the prevalent Salmonella species in broilers farms in Dakahlia Governorate, Egypt. Also, for detection of common virulence genes of Salmonella using Polymerase Chain Reaction.

\section{Material and methods}

\section{Sample collection}

A total of 200 samples from broilers farms were collected for Salmonella isolation and these samples include liver, caecum, spleen, heart and kidney. All samples were put in sterile plastic bags in ice box and transported directly to Mansoura laboratory (Animal Health Research Institute).

\section{Isolation of Salmonella according} to ISO 6579 (2002) method

Each sample was inoculated separately in selenite $\mathrm{F}$ broth and incubated at $37^{\circ} \mathrm{C}$ for not more than 18 hours or Rappaport-Vassiliadis Soya broth (RVS) and incubated at $42^{\circ} \mathrm{C}$ for 24 hours. Then a loopful 
from selective enriched media was streaked onto plates of MacConkey's, Salmonella-Shigella (S.S) and xylose lysine deoxycholate and incubated overnight at $37{ }^{\circ} \mathrm{C}$. Typical colonies were picked and further tested by standard biochemical methods and serotyped using specific commercial sera according to the Kauffmann-White scheme (Kauffmann, 1974).

Identification of Salmonella isolates:

\section{Microscopic examination}

Films from suspected purified colonies were prepared, fixed and stained with Gram's according to Quinn et al (2002) then examined microscopically

\section{Biochemical}

Identification according to ISO 6579 (2002) method:

Purified isolates were examined by different biochemical reactions either by oxidase, urea hydrolysis, $\mathrm{H}_{2} \mathrm{~S}$ production on TSI, lysine decarboxylation, indole, methyl red test, Voges-Proskauer, citrate utilization, motility test and Analytical profile index $20 \mathrm{E}$ (API $20 \mathrm{E})$

\section{Serological identification:}

The preliminarily identified isolates biochemically as Salmonella were subjected to serological identification according to Kauffman-White Scheme (Kauffman, 1974) for determination of somatic $(\mathrm{O})$ and flagellar $(\mathrm{H})$ antigens using slide agglutination test.
Detection of common virulence genes in Salmonella isolates using PCR:

1. Extraction of DNA (Oliveira et al, 2003).

2. Preparation of PCR Master Mix according to Emerald Amp GT PCR mastermix (Takara).

3. Cycling conditions of the primers during cPCR.

4. DNA Molecular weight marker.

5. Agarose gel electrophoreses (Sambrook et al, 1989).

Antibiotic sensitivity testing according to ISO $6579 \quad(2002)$ method:

Determination of the susceptibility of the isolated strains to antibiotic discs was adopted using the disc diffusion technique according to Finegold and Martin (1982).

\section{Results}

The results illustrated in Table 1 demonstrated the prevalence of Salmonella spp. in examined chickens.

Bacteriological examination of samples allover seasons of the year revealed that salmonella was recovered in 37 samples with an incidence rate $18.5 \%$ (37 out of 200) as shown in Table 1.

The recovery rate of Salmonella from internal organs is clarified in Table 2.

As shown in Table 2, a high level of Salmonella infection was found in liver $(9.5 \%)$ followed by caecum (5.5\%); spleen $(4.5 \%)$; heart $(3 \%)$ and kidney (2\%). 
All Salmonella suspected isolates showed smooth red coloured colonies with black center on XLD while on Hektone enteric it appeared as deep blue colonies but on MacConkey's agar appeared as pale, colorless smooth, transparent and raised colonies and on Salmonella Shigella (S-S) agar, Salmonella produce colourless colonies with black centers due to $\mathrm{H} 2 \mathrm{~S}$ production. The staining characters appeared as Gram negative, non-spore forming \& short rod shaped. Biochemically, all Salmonella suspected isolates were non-lactose fermenting colonies and negative oxidase, urea hydrolysis, indole and Voges-Proskauer tests. Meanwhile, most isolates produced $\mathrm{H}_{2} \mathrm{~S}$ and positive methyl red, citrate utilization and lysine decarboxylation.

The results of serotyping of isolated Salmonella species were observed in Table 3. The isolated salmonella (37) were serotyped using "O" and "H" antisera to determine the salmonella serotypes as eight $S$. enteritidis, one $S$. macclesfield, two $S$. wingrove, one $S$. eingedi, three $S$. rissen,two $S$. derby, two $S$. vejle, one $S$. magherafelt, two $S$. berta, two S. enterica sub.spp salamae, one S. gueuletapee, one S. blegdam, five $S$. kentucky, two $S$. newport, two $S$. agona, two $S$. virchow were isolated from broilers with percentage of $(21.62 \%),(2.7 \%)$, (5.4\%), (2.7\%), (8.1\%), (5.4\%), $(5.4 \%), \quad(2.7 \%),(5.4 \%), \quad(5.4 \%)$, (2.7\%), (2.7\%), (13.5\%), (5.4\%), $(5.4 \%)$ and $(5.4 \%)$ respectively.

Six salmonella serotypes ( $S$. enteritidis, S. macclesfield, S. rissen, $S$. derby, $S$. Magherafelt and $S$. enterica sub.spp salamae) examined for detection of virulence genes as invA, stn and sopB by conventional PCR. All examined serotypes have the three genes as demonstrated in photos $1,2 \& 3$.

All Salmonella isolates were tested for antibiotic sensitivity test to 10 different antibiotics. Gentamycin, ciprofloxacin, colistin sulphate and enrofloxacin were the most effective (100\% effectivity of each) followed by florphenicol (93.75\%), neomycin $(81.25 \%)$. Meanwhile, erythromycin and flumequine were the most resistant antibiotic against the isolates $(87.5 \%)$. Also, resistance to doxycycline hydrochloride was $(81.25 \%)$ and ampicillin was $(75 \%)$.

Table (1) Incidence of Salmonella infection in examined chickens

\begin{tabular}{|c|c|c|c|}
\hline Examined chicken & $\begin{array}{c}\text { Number of examined } \\
\text { chicken }\end{array}$ & $\begin{array}{c}\text { Number of } \\
\text { positive }\end{array}$ & $\%$ \\
\hline Apparently healthy chicken & 40 & 3 & 7.5 \\
\hline Diseased chicken & 80 & 21 & 26.25 \\
\hline Freshly dead chicken & 80 & 13 & 16.25 \\
\hline Total & 200 & 37 & 18.5 \\
\hline
\end{tabular}


Table (2) Rate of recovery of Salmonella from internal organs.

\begin{tabular}{|c|c|c|}
\hline $\begin{array}{c}\text { Examined organs in } \\
200 \text { chicken }\end{array}$ & $\begin{array}{c}\text { Number of } \\
\text { positive }\end{array}$ & $\begin{array}{c}\text { Percentage of } \\
\text { positive }\end{array}$ \\
\hline Liver & 19 & 9.5 \\
\hline Caecum & 11 & 5.5 \\
\hline Spleen & 9 & 4.5 \\
\hline Heart & 6 & 3 \\
\hline Kidney & 4 & 2 \\
\hline Total & 49 & 24.5 \\
\hline
\end{tabular}

Table (3) Serotyping of isolated Salmonella species

\begin{tabular}{|c|c|c|c|}
\hline $\begin{array}{c}\text { Type of isolated } \\
\text { Salmonella strains }\end{array}$ & Antigenic analysis & $\begin{array}{l}\text { Number of } \\
\text { positive } \\
\text { chicken }\end{array}$ & $\begin{array}{c}\text { Percentage of } \\
\text { positive }(\%)\end{array}$ \\
\hline $\begin{array}{l}\text { Salmonella } \\
\text { enteritidis }\end{array}$ & $\mathrm{O}: 1,9,12 . \mathrm{H} 1 \mathrm{~g}, \mathrm{~m}, \mathrm{H} 2$ & 8 & 21.62 \\
\hline $\begin{array}{l}\text { Salmonella } \\
\text { macclesfield }\end{array}$ & $\begin{array}{c}\text { O: } 9,46 . \mathrm{H} 1 \mathrm{~g}, \mathrm{~m}, \mathrm{~S}, \mathrm{H} 2 \\
1,2,7 .\end{array}$ & 1 & 2.7 \\
\hline $\begin{array}{l}\text { Salmonella } \\
\text { Wingrove }\end{array}$ & O: 6,8. H1 C, H2 1,2 & 2 & 5.4 \\
\hline Salmonella eingedi & $\begin{array}{c}\text { O: 6,7. H1 F,g,t, H2 } \\
1,2,7\end{array}$ & 1 & 2.7 \\
\hline Salmonella rissen & $\mathrm{O}: 6,7,14 . \mathrm{H} 1 \mathrm{f}, \mathrm{g} . \mathrm{H} 2$ - & 3 & 8.1 \\
\hline Salmonella derby & $\begin{array}{c}\text { O: } 1,4,[5], 12 . \mathrm{H} 1 \mathrm{~F}, \mathrm{~g} . \\
\mathrm{H} 2[1,2]\end{array}$ & 2 & 5.4 \\
\hline Salmonella Vejle & $\begin{array}{c}\text { O: } 3,[10],[15] . \mathrm{H} 1 \mathrm{e}, \mathrm{h}, \\
\mathrm{H} 21,2\end{array}$ & 2 & 5.4 \\
\hline $\begin{array}{l}\text { Salmonella } \\
\text { magherafelt }\end{array}$ & O: 8,20. H1 I, H2 1,w & 1 & 2.7 \\
\hline Salmonella berta & $\begin{array}{c}\text { O: } 1,9,12 . \mathrm{H} 1[\mathrm{~F}], \mathrm{g},[\mathrm{t}] \\
\mathrm{H} 2-\end{array}$ & 2 & 5.4 \\
\hline $\begin{array}{l}\text { Salmonella enterica } \\
\text { sub.spp salamae }\end{array}$ & $\begin{array}{c}\text { O: 1,4,[5],12.H1 F,g,t. } \\
\text { H2 Z6 }\end{array}$ & 2 & 5.4 \\
\hline $\begin{array}{l}\text { Salmonella } \\
\text { gueuletapee }\end{array}$ & $\mathrm{O}: 9,12, \mathrm{H} 1 \mathrm{~g}, \mathrm{~m}, \mathrm{~s}, \mathrm{H} 2$ & 1 & 2.7 \\
\hline Salmonella blegdam & $\mathrm{O}: 9,12, \mathrm{H} 1 \mathrm{~g}, \mathrm{~m}, \mathrm{q}, \mathrm{H} 2$ & 1 & 2.7 \\
\hline Salmonella kentucky & O: 8,20. H1: i, H2: Z6 & 5 & 13.5 \\
\hline Salmonella newport & $\begin{array}{c}\mathrm{O}: 6,8,20 . \mathrm{H} 1: \mathrm{e}, \mathrm{h}, \mathrm{H} 2 \\
: 1,2\end{array}$ & 2 & 5.4 \\
\hline Salmonella agona & $\begin{array}{c}\mathrm{O}: 1,4(5), 12 . \mathrm{H} 1: \mathrm{f}, \mathrm{g}, \mathrm{s}, \\
\mathrm{H} 2:(1,2)\end{array}$ & 2 & 5.4 \\
\hline Salmonella virchow & $\mathrm{O}: 6,7,14 . \mathrm{H} 1: \mathrm{r}, \mathrm{H} 2: 1,2$ & 2 & 5.4 \\
\hline
\end{tabular}




\begin{tabular}{|l|l|l|l|l|l|l|l|l|}
\hline Neg & 1 & 2 & Pos & L & 3 & 4 & 5 & 6 \\
\hline
\end{tabular}

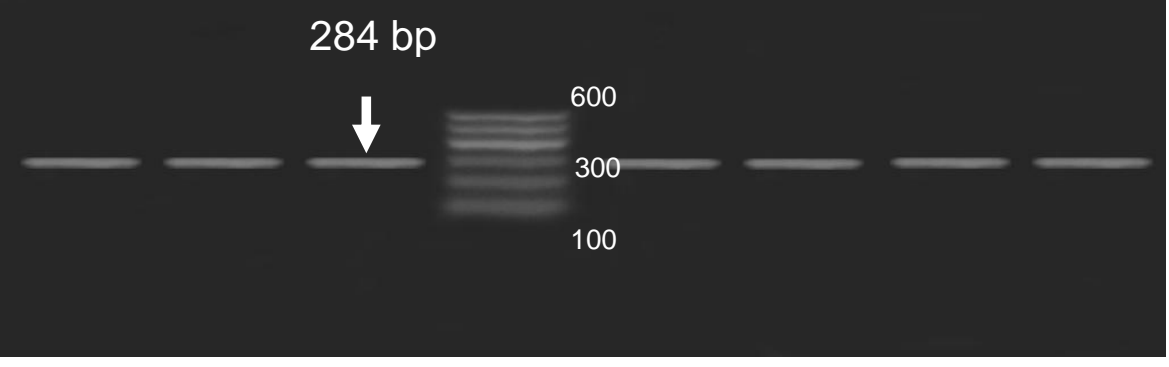

Photo (1): Agarose gel electrophoresis showing Salmonella specific PCR of Salmonella isolates using primer set for the invA (284 bp) gene. Lane L: 100-600pb DNA ladder; Pos.: Positive control; Neg.: Negative control; Lane 1, 2,3,4,5 \&6 examined Salmonella.

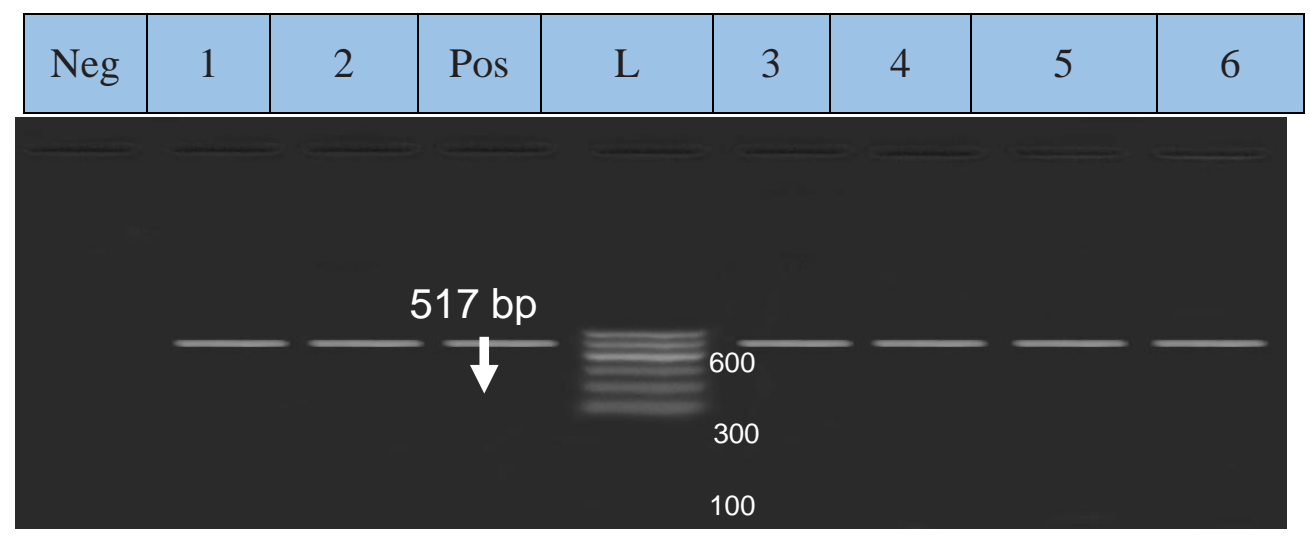

Photo (2): Agarose gel electrophoresis showing Salmonella specific PCR of Salmonella isolates using primer set for the $\operatorname{sop} \mathrm{B}$ gene $(517 \mathrm{bp})$. Lane L: 100-600pb DNA ladder; Pos.: Positive control; Neg.: Negative control; Lane 12,3,4,5 \&6 examined Salmonella. 

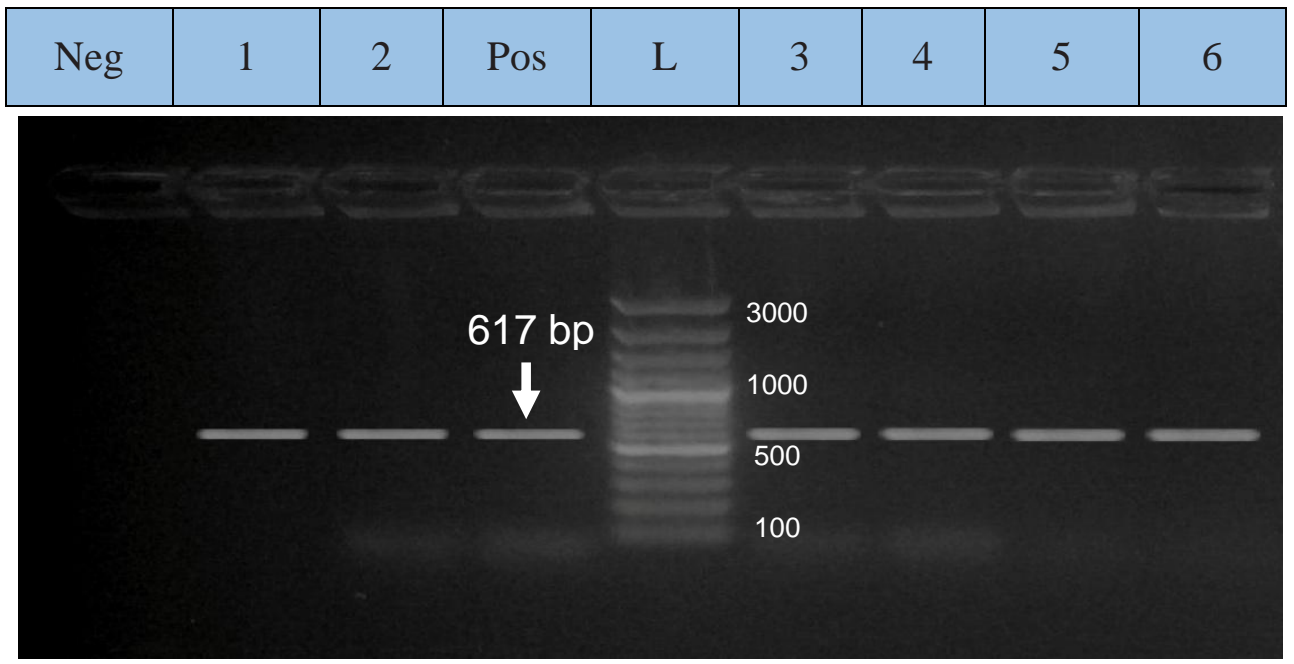

Photo (3): Agarose gel electrophoresis showing Salmonella specific PCR of Salmonella isolates using primer set for the stn (617 bp) gene. Lane L: 1003000pb DNA ladder; Pos.: Positive control; Neg.: Negative control; Lane 1, 2,3,4,5 \&6 examined Salmonella.

\section{Discussion}

Salmonella infection is one of the most important bacterial diseases in poultry causing heavy economic loss through mortality and reduced production Haider et al (2004). In the present study, the incidence of Salmonella in broilers was $18.5 \%$ (37 out of 200 chickens) and these results agree with Kudaka et al (2006) who found that $18 \%$ of broilers were positive for salmonella. Also, EFSA (2007) reported that Salmonella spp. present with $20.3 \%$ in the broiler flocks in the European Union and Kaushik et al., (2014) isolated Salmonella from chicken meat with $23.7 \%$. On the other hand, lower incidence was recorded by Hassan et al (2003) (5.51\%) and Abd El-Ghany et al (2012)
(4.48\%). However, Bada-Alambedji et al (2006) reported that Salmonella present in $(62.5 \%)$ in examined chickens with higher incidence. The difference in the prevalence rates may be due to socio-economic factors.

Recovery of Salmonella species from internal organs of the examined chickens were higher from liver followed by caecum, spleen, heart and kidney 9.5\%, $5.5 \%, \quad 4.5 \%, \quad 3 \%$ and $2 \%$ respectively. It was clear from these results, showed higher isolation rate of Salmonella species from liver and this similar to Chaiba et al (2009) isolated a higher level of Salmonella from liver (11.11\%). However, Cox et al (2007) isolated higher level of Salmonella from spleens followed by liver and ceca 
of 6 weeks old broilers with $15 \%, 10 \%$ and $8 \%$ respectively while in 8 weeks old broilers, were $51 \%, 48 \%$ and $65 \%$ of the livers, spleens, and ceca, respectively. But, Selvaraj et al (2010) found that the higher percentage of Salmonella spp. were isolated from chicken meat $(8.00 \%)$ followed by liver and spleen $(6.25 \%$ each), intestine and intestinal contents $(5.26 \%)$, kidney and gall bladder (3.57\%).

Serological identification of isolated Salmonella species revealed higher incidence of $S$. enteritidis $(21.62 \%)$ followed by $S$. kentucky(13.5\%), $S$. rissen $(8.1 \%), 5.4 \%$ for each $S$. wingrove, $S$. derby, $S$. vejle, $S$. berta, S. enterica sub.spp salamae, $S$. newport, $S$. agona \& S. virchow and $2.7 \%$ for each S. maccles field, $S$. eingedi, $S$. magherafelt, $S$. gueuletapee \& S. blegdam. These results agree with that reported by Nagwa et al (2012); Dahal (2007); Kanashiro et al (2005); Shah and Korejo (2012); Putturu et al (2012) and Abd El-Ghany et al (2012). They recorded that the predominant serotypes of Salmonella was $S$. enteritidis. In contrast, Kaushik et al (2014) isolated $S$. enteritidis with $0.4 \%$ and $S$. newport with $2.6 \%$. Moreover, Roy et al (2002) isolated S. Kentucky and Salmonella enteritidis with percentage of $21.64 \%$ and $5.15 \%$, respectively.

Oliveira et al (2003) revealed that PCR method is high specificity and sensitivity and more importantly a less time-consuming procedure than standard microbiological techniques for detection and identification of Salmonella. PCR assay using the invA primers specific for Salmonella spp. considerably decreases the number of falsenegative results which commonly occur in diagnostic laboratories. Amplification of invA is now recognized as an international standard procedure for detection of Salmonella genus. In this study, PCR assay was carried out for the detection of the invA gene from six isolated strains ( $S$. enteritidis, $S$. macclesfield, S. rissen, S. derby, $S$. magherafelt and S. enterica sub.spp salamae) has revealed that the gene was present in all of the isolates $(100 \%)$ that was demonstrated by the presence of a 284 bp PCR amplified fragment. The results obtained in the present study were in corroboration with Malmarugan et al (2011); Nagappa et al (2007) and Dione et al (2011). PCR assay was carried out for the detection of the $s o p \mathrm{~B}$ gene from isolated strains has revealed that the gene was present in all of the isolates $(100 \%)$ which was demonstrated by the presence of a 517 bp PCR product. The results obtained in the present study were in corroboration with Eckmann et al (1997). Also, PCR assay carried out for the detection of the stn gene in Salmonella isolates has revealed that the gene was present in all the isolates $(100 \%)$ that was demonstrated by the presence of a 617 bp PCR product. These findings are in 
agreement with Murugkar et al (2003); Prager et al (1995) and Rahman H. (1999). Observations from the present study indicated that the stn gene is widely distributed among the Salmonella serovars.

In this study all Salmonella strains were sensitive to gentamycin, ciprofloxacin, colistin sulphate and enrofloxacin and this agree with Ramachandranpillai

Mangattumuruppel (2013) who reported that all the strains were sensitive to at least four antibiotics as gentamicin, chloramphenicol, ceftriaxone and ciprofloxacin. But on the contrary Yah and Eghafona (2007) reported that the isolates were highly resistant to ampicillin, chloramphenicol, gentamycin and tetracycline and this agree with the present study as all examined salmonellae were resistant to ampicillin except $S$. enteritidis, $S$. derby, $S$. agona and $S$. wingrove. Abd El-Rahman et al (2000) reported that salmonella species were sensitive to enrofloxacin and this agrees with the present study. It could be concluded that there are high level of Salmonella isolation in broilers evaluated in this study may be attributed to horizontal and/or vertical transmission of Salmonella to the chicks. Also, the high rates of antibiotics resistance found in the present study can be explained by the abuse of antibiotics agents given to poultry in Egypt as prophylaxis, growth promoters or treatment. The multiple resistances observed were to those antimicrobials frequently employed in veterinary practices. We recommend more restrictions on the irrational use of antibiotics and public awareness activities should be undertaken to alert the public to the risks of the unnecessary use of antibiotics. Also, the study recommends that PCR should be used for rapid and sensitive detection of Salmonella.

\section{References}

Abd El-Ghany, Wafaa A.; ElShafii, Soumaya S.A. and M.E. Hatem (2012): A Survey on Salmonella species isolated from chicken flocks in Egypt. Asian journal of animal and veterinary advances.7 (6):489-501.

Abd-El-Rahman, A.; Mahmoud, A.; and Moussa, H. M. (2000): Bacteriological and histopathological studies on Salmonella isolates from ducks in North Sinai. Egyptian Journal of Agricultural Research.78 (1): 15-24. Ammar, A.; Y.A. Ahmed; A. Esawy and A. Ibrahim, (2010): Bacteriological studies on salmonella entertidis isolated from different sources in Dakhlia governorat. Assiut Vet. Med. J., 56(124): 125-135.

Bada-Alambedji, R.; Fofana, A.; Seydi, M. and Akakpo, A. (2006): Antimicrobial resistance of Salmonella isolated from poultry carcasses in Dakar (Senegal). Brazilian Journal of Microbiology. 37: 510 - 515 . 
Chaiba, A.; Rhazi, F. F.; Chahlaoui, A.; Soulaymani, B. R. and $M$. Zerhouni (2009): Prevalence and anti-microbial susceptibility of Salmonella isolates from chicken carcass and giblets in Meknes, Morocco. African Journal of microbiology Reaserch 3(5):215219.

Chiu, Lan-Ho; Chiu, ChengHsun; Yan-Ming Horn; ChienShun, Chiou; Chien-Yu, Lee; Chia-Ming, Yeh; Chang-You, Yu; Chean-Ping, Wu; Chao-Chin, Chang and Chishih, Chu (2010): Characterization of 13 multi-drug resistant Salmonella serovars from different broiler chickens associated with those of human isolates. BMC Microbiology, 10:86.

Cox, N.A.; Richardson, L.J.; Buhr, R.J.; Northcutt, J.K.; Bailey, J.S.; Cray, P.F. and Hiett, K.L. (2007): Recovery of Campylobacter and Salmonella Serovars from the Spleen, Liver and Gallbladder, and Ceca of Six- and Eight-Week-Old Commercial Broilers. Appl. Poult. Res. 16:477480.

Dahal, N. (2007): Prevalence and Antimicrobial Resistance of Salmonella in Imported Chicken Carcasses in Bhutan, Master of Veterinary Public Health, Chiang Mai University and Freie Universität Berlin. P: 47.

Dione, M.M.; Saha, D.; Mohammed, N.I.; Adegbola, R.A.; Ieven, M. and Antonio, M. (2011): Antimicrobial resistance and virulence genes of non- typhoidal Salmonella isolates in The Gambia and Senegal. J .Infect. Dev. Ctries, 5, 765-775.

Eckmann, L.; Rudolf, M.T.; Ptasznik, A.; Schultz, C.; Jiang, T.; Wolfson, N.; Tsien, R.; Fierer, J.; Shears, S.B.; Kagnoff, M.F. and Traynor-Kaplan, A.E. (1997): D-myo-Inositol 1,4,5,6tetrakisphosphate produced in human intestinal epithelial cells in response to Salmonella invasion inhibits phosphoinositide 3-kinase signaling pathways. Proc Natl Acad Sci USA 94, 14456-14460.

European Food Safety Authority (EFSA) (2007): Report of the Task Force on Zoonoses Data Collection on the Analysis of the baseline survey on the prevalence of Salmonella in broiler flocks of Gallus gallus, Part A, The EFSA Journal (2007) 98, 1-85.

Finegold, S. M. and Martin, E. T. (1982): Diagnostic microbiology. 6th Ed., The C.V. Mosby Company, St. Louis, Toronto, London.

Forshell, L.P. and Wierup, M. (2006): Salmonella contamination: a significant challenge to the global marketing of animal foods products. Revue Scientifique Techinique Office International des Epizooties, 25(2): 541-554.

Gallegos, R.; Loredo, A.; Ojeda, G. and Vega, A. (2008): Identification of Salmonella serotypes isolated from cantaloupe and chile pepper production system in Mexico using PCR-RFLP. J. Food Protect., 71(11): 2217-2222. 
Haider, M.; Hossain, M.; Kudaka, J.; Itokazy, K.; Taira, Chowdhury, E. and Das, P. K.; Iwai, A.; Kond, M.; Sua, T. (2004): Isolation and characterization of Enterobacteria Associated with Health and Disease in Sonali Chickens. Banganladesh Journal of Veterinary Medicine. 2 (1): 15-21.

Hassan, W.M.M.; Oraby, F.A.I. and Hassan, A.M. (2003): Comparative studies on different isolates of avian Salmonellae by sodium dodocyl sulphate polyacrylamide gel electrophoresis (SDS-PAGE). J. Egypt. Med. Assoc., 63 (2): 65-72.

ISO 6579 (2002): Microbiology of food and animal feeding stuffshorizontal method for the detection of Salmonella Spp. International standard. (Fourth edition).

Kanashiro, A. M. I.; G. F. Z. Stoppa; A. L. S. P. Cardoso; E. N. C. Tessari and A. G. M. Castro (2005): Serovars of Salmonella spp. isolated from broiler chickens and commercial breeders in diverse regions in Brazil from July 1997 to December 2004. Revista Brasileira de Ciência Avícola, 7, 195-198.

Kauffman, F. (1974): Serological diagnosis of Salmonella species. Kauffman white scheme Minkagaord, Copenhagen, Denmark.

Kaushik, P.; Anjay; Kumari, S.; Bharti, S.K. and Dayal, S. (2014): Isolation and prevalence of Salmonella from chicken meat and cattle milk collected from local markets of Patna, India, Veterinary World 7(2): 62-65. and Iwanaga, M. (2006): Characterization of Salmonella Isolated in Okinawa, Japan. Japan. J. Infect .Dis. 59: 15 - 19.

Malmarugan, Shanmugasamy; Thenmozhi, Velayutham and Johnson, Rajeswar (2011): Inv A gene specific PCR for detection of Salmonella from broilers. Vet. World, 4(12):562-564.

Murugkar, H.; Rahman, H. and Dutta, P. (2003): Distribution of virulence genes in Salmonella serovars isolated from man \& animals. Indian J Med Res. 117: 66 -70 .

Nagappa, K.; Tamuly, S.; Brajmadhuri, Saxena, M. and Singh, S. (2007): Isolation of Salmonella Typhimurium from poultry eggs and meat of Tarai region of Uttaranchal. Indian Journal of Biotechnology. 6. 407409.

Nagwa, S. Rabie; Nashwa, O. Khalifa; Mervat, E.I. Radwan and Jehan, S.A. Afify (2012): Epidemiological and Molecular Studies of Salmonella isolates from Chicken, Chicken Meat and Human in Toukh, Egypt. Global Veterinaria 8 (2): 128-132.

Oliveira, S.D.; Rodenbusch, C.R.; Cé, M.C.; Rocha, S.L. and Canal, C.W. (2003): Evaluation of selective and non-selective enrichment PCR procedures for Salmonella detection. Lett Appl Microbiol. 36(4):217-221. Popoff, M.Y. and Minor, L.L. 
(1997): Antigenic formulas of the Salmonella serovars, 7th revision. W.H.O. Collaborating Centre of Reference and Research on Salmonella Institute Pasteur, Paris, France.

Prager, R.; Fruth, A. and Tschape, H.(1995): Salmonella enterotoxin (stn) gene is prevalent among strains of Salmonella enterica but not among Salmonella bongori and other Enterobacteriaceae. FEMS Immunol Med Microbiol; 12 : 4750.

Putturu, Ramya; Thirtham, Madhavarao and Lakkineni, Venkateswara, Rao (2012): Study on the incidence of Salmonella enteritidis in poultry and meat samples by cultural and PCR methods. Vet. World, 5 (9):541545.

Quinn, P.J.; B.K. Markey; M.E. Carter; W.J. Donnelly and F.C. Leonard (2002): Veterinary Microbiology and Microbial Diseases. 1st Edn., WileyBlackwell Science, USA., 544-549.

Rahman, H. (1999): Prevalence of enterotoxin gene (stn) among different serovars of Salmonella. Indian J Med Res; 110: 43-6.

Ramachandranpillai, Rajagopal and Mangattumuruppel, Mini (2013): Outbreaks of salmonellosis in three different poultry farms of
Kerala, India, Asian Pac J Trop Biomed; 3(6): 496-500.

Roy, p.; Dhillon, A.S.; Lauerman, L.H.; Schaberg, D.M.; Bandli, D. and Johnson, S. (2002): Results of Salmonella isolation from poultry products, environment and other characteristics. Avian Dis., 13: 793803.

Sambrook, J.; Fritscgh, E.F. and Mentiates (1989): Molecular coloning. A laboratory manual. Vol, Cold spring Harbor Laboratotry press, New York.

Selvaraj, R.; Das, R.; Ganguly, S.; Ganguli, M.; Dhanalakshmi, S. and Mukhopadhayay, S. K. (2010): Characterization and antibiogram of Salmonella spp. from poultry specimens. Journal of Microbiology and Antimicrobials. 2(9): 123-126.

Shah and N. A. Korejo (2012): Antimicrobial Resistance Profile of Salmonella Serovars isolated from Chicken meat. J. Vet. Anim. Sci. 2: 40-46.

Van Asten, A.J.A.M. and van Dijk, J.E. (2005) Distribution of classic virulence factors among Salmonella spp. FEMS Immunol. Med. Micribiol., 44, 251-259.

Yah, S.C. and Eghafona, N.O. (2007): Plasmids: A vehicle for rapid transfer of antibiotic resistance markers of salmonella species in animals. J. Amer. Sci., 3 (4): 86-92. 


\section{تواجد وتوصيف أنواع السالمونيلا المعزولة من بدارى التسمين التمبين

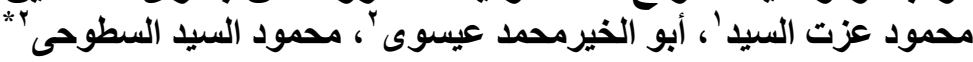

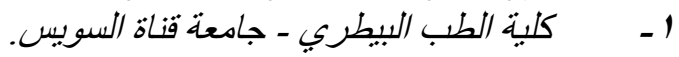

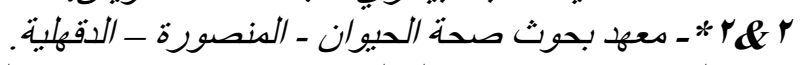

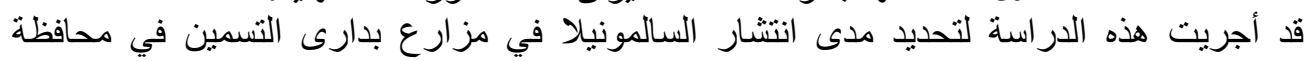

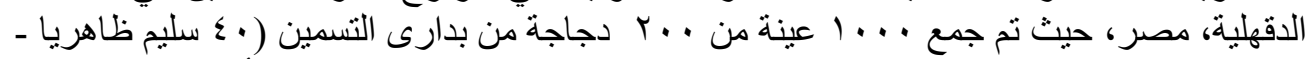

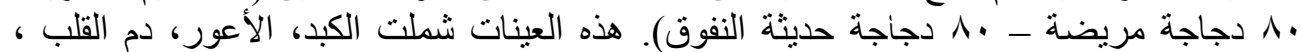

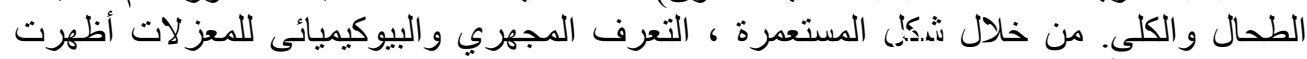

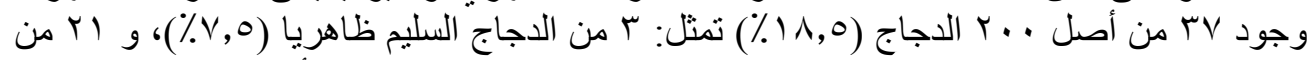

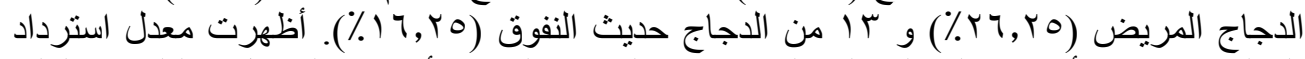

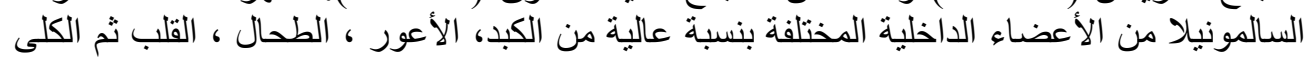

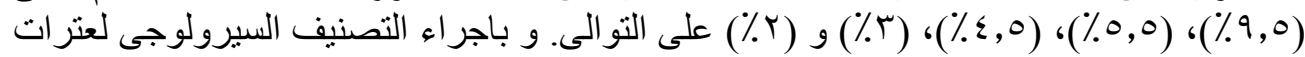

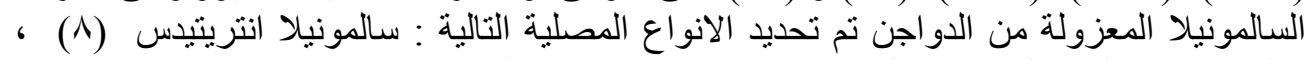

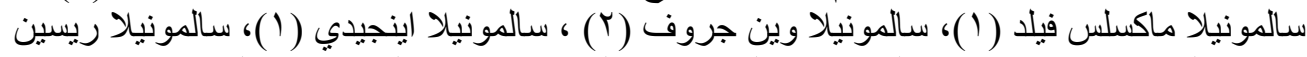

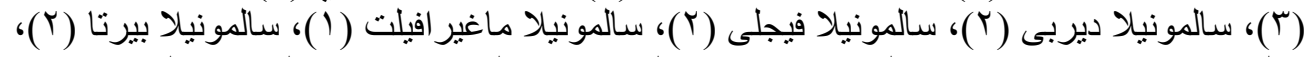

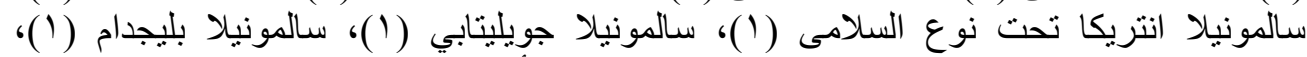

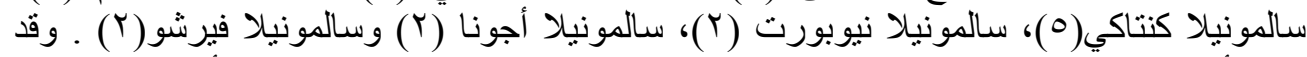

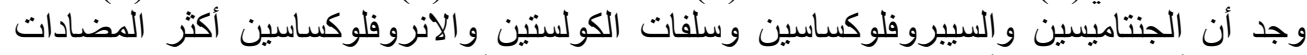

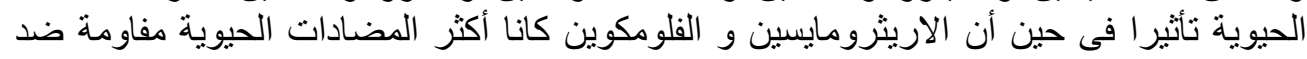

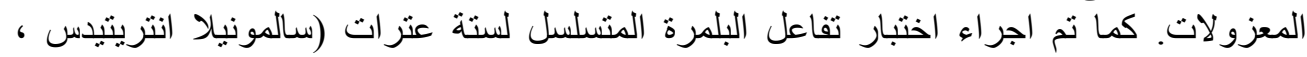

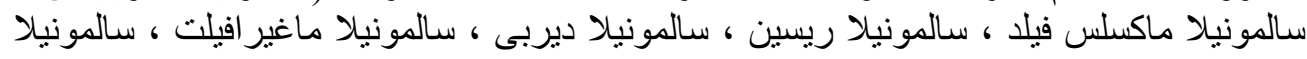

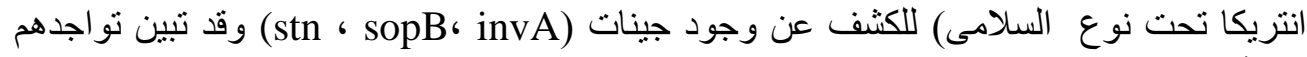

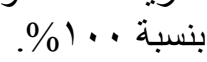

